\title{
HUBUNGAN PENDAMPINGAN KELUARGA DENGAN \\ LAMA PROSES PERSALINAN KALA I \\ DI PUSKESMAS KARANGDORO \\ KOTA SEMARANG
}

\section{THE CORRELATION OF FAMILY ASSISTANCE WITH THE DURATION OF LABOR IN THE FIRST STAGE OF KARANGDORO COMMUNITY HEALTH CENTER AT SEMARANG CITY}

\author{
Widyah Setiyowati ${ }^{1)}$ Mursini $^{2}$ ) \\ 1)2) Akademi Kebidanan Abdi Husada Semarang \\ Email : wiwidwidyah@yahoo.com
}

\begin{abstract}
ABSTRAK
Support system yang diberikan kepada ibu menjelang persalinan sangat mendukung dalam menurunkan tingkat kecemasan pada ibu pada saat persalinan. Keuntungan pendamping persalinan oleh keluarga dapat mengurangi rasa cemas, mempercepat proses persalinan, menghindari komplikasi-komplikasi pada persalinan, mengurangi nilai score APGAR $<7$ pada bayi baru lahir sehingga menghindari bayi asfeksia, waktu yang di butuhkan dalam proses persalinan semakin pendek, kepuasan ibu semakin meningkat dalam pengalaman melahirkan, persalinan yang diakhiri dengan vacuum ekstraksi, fosceps, dan secsio cesaria semakin menurun. Mengetahui hubungan pendampingan keluarga dengan lama proses persalinan kala I di Puskesmas Karangdoro Kota Semarang. Penelitian ini menggunakan rancangan cross sectional dan jenis penelitian deskriptif analitik. Populasi dalam penelitian ini sebanyak 39 responden, menggunakan teknik sampel Total populasi yaitu semua ibu Primipara yang bersalin di puskesmas Karangdoro Semarang sebanyak 39 responden. Analisa yang digunakan univariat dan bivariat menggunakan uji chi-square. Hasil dari penelitian yaitu sebagian besar ibu dalam proses persalinan kala I mendapatkan pendampingan keluarga yang baik selama proses persalinan kala 1 sebanyak 24 (72,7\%) responden; Sebagian besar ibu mengalami proses persalinan kala 1 cepat sebanyak 21 (63, 6\%) responden; Ada hubungan yang bermakna antara pendampingan keluarga dengan lama proses persalinan di Puskesmas Karangdoro Semarang dengan nilai continuity correction sebesar 3,275 dengan $p$ value fisher exact sebesar 0,044<0,05. Ada hubungan yang bermakna antara pendampingan keluarga dengan lama proses persalinan di Puskesmas Karangdoro Semarang. Masyarakat diharapkan menambah wawasan tentang pendampingan keluarga pada proses persalinan kala I, sehingga masyarakat tidak merasa tabu dan takut dalam mendampingi persalinan kala I pada ibu bersalin.
\end{abstract}

Kata kunci : : pendampingan keluarga, proses persalinan.

\section{ABSTRACT}

The support system given to the mother prior to childbirth is very supportive in reducing the level of anxiety in the time of delivery. The benefits of family accompaniment for birth can reduce anxiety, accelerate labor, avoid complications in labor, reduce the score of APGAR $<7$ in newborns to avoid asphyxia infants, the time required in the process of delivery is shorter, In the experience of childbirth, labor ending with vacuum extraction, fosceps, and cesaria secsio decreases. To find the correlation of family assistance with the duration of labor process in the first stage of Karangdoro Community Health Center at Semarang City. This research use cross sectional design and analytic descriptive research type. Population in this research as many as 39 respondents, using sample technique Total population that is Primipara delivering in Karangdoro Community Health Center Semarang counted 39 respondents. The analysis used univariate and bivariate using chi-square test. Most mothers in the first stage of labor received good family assistance as many as 24 (72.7\%) respondents; Most of the mothers experienced a rapid in the first stage of labor as many as 21 (63, 6\%) respondents; There is a significant cerrelation between family assistance with the duration of labor process in the first stage of Karangdoro Community Health Center at Semarang City with continuity correction value 3,275 with p value fisher exact 0,044 $<0,05$. There is a significant correlation between family assistance with the duration of labor in the first stage of Karangdoro Community Health Center at Semarang City. The community is expected to add insight about the family's assistance in the process of labor in first stage, so that people do not feel taboo and fear in accompanying the first stage of labor on maternity.

Keywords: family accompaniment, labor process.

Copyright (C) 2017, JK, p-ISSN: 2301-8372, e-ISSN: 2549-7081 


\section{PENDAHULUAN}

Intervensi strategis dalam upaya Safe Motherhood dinyatakan sebagai empat pilar Safe Motherhood, yaitu pertama Keluarga Berencana yang memastikan bahwa setiap pasangan/orang mempunyai akses ke informasi dan pelayanan KB. Kedua pelayanan antenatal guna untuk mencegah adanya komplikasi obstetri yang mungkin terjadi, ke tiga persalinan yang aman memastikan bahwa semua penolong persalinan mempunyai pengetahuan, ketrampilan dan alat untuk memberikan pertolongan yang aman dan bersih. Ke empat pelayanan obtetri esensial memastikan bahwa pelayanan obstetri untuk resiko tinggi terjadi dan komplikasi bagi ibu hamil yang membutuhkan.

Proses persalinan merupakan salah satu faktor yang dapat menimbulkan kecemasan, karena proses melahirkan bayi tidak selalu bersifat somatik. Akan tetapi, juga bersifat psikosomatis, karena banyak hal yang dapat mempengaruhi kelancaran atau keterlambatan proses persalinan. Pada hakekatnya seorang wanita dalam proses persalianan mempunyai 5 (lima) kebutuhan yaitu asuhan fisik, psikologis, kehadiran seorang pendamping secara terusmenerus, pengurangan rasa sakit, penerimaan atas sikap dan perilaku, serta informasi dan kepastian tentang hasil persalinan yang aman.

Untuk mengatasi kecemasan dan mengurangi nyeri waktu bersalin dapat dengan cara non farmakologik yaitu dengan pendekatan-pendekatan psikologis yang dilakukan oleh bidan, dokter dan orang-orang disekitarnya terutama suaminya sendiri dengan memotivasi calon ibu dalam menghadapi persalinannya dan berusaha untuk menyakinkan calon ibu bahwa kehamilannya itu adalah hal yang normal dan wajar selain itu, metode teknik pernafasan dan relaksasi yaitu dengan latihan ringan, istirahat yang cukup dan nutrisi yang baik serta sikap positif dalam menghadapi persalinan juga dapat mengurangi rasa cemas dengan menyakinkan diri. Keberadaan pendamping akan membawa dampak yang baik pada proses persalinan karena dapat memberikan dukungan, semangat, dan rasa aman.jika seorang wanita ingin didampingi selama proses persalinan, mintalah kepada suami atau keluarga yang terdekat.

Support system yang diberikan kepada ibu menjelang persalinan sangat mendukung dalam menurunkan tingkat kecemasan pada ibu dalam berlangsungnya persalinan. Keuntungan pendamping persalinan oleh keluarga dapat mengurangi rasa cemas, mempermudah atau mempercepat proses persalinan serta dapat menghindari komplikasi-komplikasi pada persalinan, dapat mengurangi nilai skore APGAR $<7$ pada bayi baru lahir sehingga menghindari bayi asfeksia, Dengan pendampingan keluarga waktu yang di butuhkan dalam menghadapi persalinan semakin pendek, kepuasan ibu semakin meningkat dalam pengalaman melahirkan, persalinan yang diakhiri dengan vacuum ekstraksi, fosceps, dan secsio cesaria semakin menurun. Pada saat proses persalinan berlangsung sebaiknya ibu bersalin ditunggui seorang bidan yang berperan melakukan observasi dan diharapkan dapat meningkatkan kepercayaan dan rasa nyaman pada fasilitas yang lebih modern kamar bersalin dibuat seperti rumah keluarga dimana suami diperbolehkan masuk dan menunggu. Pimpinan persalinan pada (kala pembukaan) ini sangat membantu dimana ibu akan dipertahankan kekuatan moral dan emosinya karena persalinan masih jauh sehingga dapat mengumpulkan kekuatan.

Jumlah cakupan persalinan dikota Semarang sebanyak 90\%. Puskesmas kaarangdoro merupakan salah satu 
puskesmas yang menggunakan pendampingan persalinan. Berdasarkan studi pendahuluan yang di lakukan pada bulan Oktober 2011, dengan metode wawancara kepada $10 \mathrm{ibu}$ bersalin normal di puskemas karangdoro Semarang. Didapatkan $6 \quad(60 \%)$ ibu bersalin primipara untuk menghadapi proses persalinan membutuhkan waktu $\geq$ 10 jam. Dan ibu mengatakan merasa cemas, takut dan kurang percaya diri dalam menghadapi proses persalinan tanpa didampingi keluarga. Dan 4 (40\%) ibu bersalin multipara untuk menghadapi proses persalinan membutuhkan waktu $<$ 10 jam. Ibu mengatakan tenang dan percaya diri dalam menghadapi proses persalinan tanpa didampingi keluarga.

Berdasarkan latar belakang di atas, peneliti ingin mengetahui "Hubungan pendampingan keluarga dengan lama proses persalinan kala I di Puskesmas Karangdoro Kota Semarang."

\section{METODE PENELITIAN}

Penelitian ini termasuk jenis penelitian kuantiatif dengan metode deskriptif analitik yang mengkaji hubungan antara dua variabel pada suatu situasi atau kelompok subyek. Rancangan penelitian ini menggunakan pendekatan cross sectional yaitu menekankan pada waktu pengukuran atau observasi data variabel independen dan dependen hanya satu kali pada saat itu juga.

Populasi dalam penelitian ini adalah semua primipara di Puskesmas Karangdoro Kota Semarang dengan jumlah 39 orang. Sampel yang digunakan sejumlah 39 orang. Tehnik sampling yang digunakan adalah Total Populasi. Analisa yang digunakan dalam penelitian ini adalah Chi Square

\section{HASIL DAN PEMBAHASAN}

A. Karakteristik Responden

Karakteristik responden hasil penelitian yang dilakukan di Puskesmas Karangdoro Kota Semarang dapat dilihat pada tabel dibawah ini
Tabel 1. Distribusi Frekuensi Umur Ibu Bersalin

\begin{tabular}{llcc}
\hline No & Umur & Frekuensi & Persentase \\
\hline 1. & $20-25$ tahun & 19 & 48,7 \\
2. & $26-30$ tahun & 15 & 38,5 \\
3. & $31-35$ tahun & 5 & 12,8 \\
\hline Jumlah & $\mathbf{3 9}$ & $\mathbf{1 0 0}$ \\
\hline
\end{tabular}

Berdasarkan Tabel 1 dapat diketahui bahwa sebagian besar ibu dalam proses persalinan kala 1 di puskesmas Karangdoro Kota Semarang berumur antara $20-25$ tahun sebanyak 19 $(48,7 \%)$ responden

Tabel 2. Distribusi frekuensi Umur Ibu bersalin di Puskesmas Karangdoro Kota Semarang

\begin{tabular}{|c|c|c|c|}
\hline No & Pendidikan & Frekuensi & Persentase \\
\hline 1. & SD & 8 & 20,5 \\
\hline 2. & SMP & 10 & 25,6 \\
\hline 3. & SMA & 18 & 46,2 \\
\hline 4. & D3\&S1 & 3 & 7,7 \\
\hline \multicolumn{2}{|c|}{ Jumlah } & 39 & 100 \\
\hline \multicolumn{4}{|c|}{$\begin{array}{l}\text { Berdasarkan Tabel 2. Sebagian besar } \\
\text { responden penelitian } \\
\text { pendidikan SMA sebanyak } 18(46,2 \%) \\
\text { responden }\end{array}$} \\
\hline
\end{tabular}

B. Analisa Univariat

1. Pendampingan Keluarga

Tabel 3. Distribusi Frekuensi

Pendampingan keluarga

\begin{tabular}{llll}
\hline No & Umur & Frekuensi & Persentase \\
\hline 1. & Baik & 27 & 69,2 \\
2. & Kurang & 12 & 30,8 \\
\hline Jumlah & $\mathbf{3 9}$ & $\mathbf{1 0 0}$ \\
\hline
\end{tabular}

Berdasarkan Tabel 3. dapat diketahui bahwa sebagian besar ibu dalam proses persalinan kala 1 di puskesmas Karangdoro Kota Semarang mendapatkan pendampingan keluarga yang baik selama proses persalinan kala 1 sebanyak $27 \quad(69,2 \%)$ responden. Tujuan utama dari pendampingan persalinan adalah untuk memberi dukungan secara fisik emosional dan psikologi sehingga proses persalinan mempunyai makna yang positif 
baik bagi ibu, suami, anak dan keluarganya.

2. Lama Proses Persalinan Kala I

Tabel 4 Distribusi frekuensi Lama

Proses Persalinan Kala I

\begin{tabular}{llll}
\hline No & $\begin{array}{l}\text { Lama } \\
\text { persalinan }\end{array}$ & Frekuensi & Persentase \\
\hline 1. & Cepat & 25 & 64,1 \\
2. & Lambat & 14 & 35,9 \\
\hline Jumlah & $\mathbf{3 9}$ & $\mathbf{1 0 0}$ \\
\hline
\end{tabular}

Berdasarkan Tabel 4. dapat diketahui bahwa sebagian besar ibu bersalin di Puskesmas Karangdoro Kota Semarang mengalami proses persalinan kala 1 yang cepat sebanyak 25 $(64,1 \%)$ responden.

\section{Analisa Bivariat}

Hubungan Pendampingan Keluarga dengan Lama Proses Persalinan Kala I di Puskesmas Karangdoro Kota Semarang

Tabel 5. Tabel Silang Pendampingan Keluarga dengan Lama Proses Persalinan Kala 1 di Puskesmas Karangdoro Kota Semarang

\begin{tabular}{|c|c|c|c|c|c|c|c|}
\hline \multirow{3}{*}{ No } & \multirow{3}{*}{$\begin{array}{c}\text { Pendampingan } \\
\text { keluarga }\end{array}$} & \multicolumn{4}{|c|}{$\begin{array}{c}\text { Lama Proses } \\
\text { persalinan kala I }\end{array}$} & \multirow{2}{*}{\multicolumn{2}{|c|}{ Total }} \\
\hline & & \multicolumn{2}{|c|}{ Cepat } & \multicolumn{2}{|c|}{ Lambat } & & \\
\hline & & f & $\%$ & f & $\%$ & f & $\%$ \\
\hline 1. & Baik & 21 & 53,8 & 6 & 15,4 & 27 & 69,2 \\
\hline 2. & Kurang & 4 & 10,3 & 8 & 20,5 & 12 & 30,8 \\
\hline & Jumlah & 25 & 64,1 & 14 & 35,9 & 39 & 100,0 \\
\hline$P$ va & 0,012 & & & & & & \\
\hline
\end{tabular}

Berdasarkan tabel silang tersebut diatas maka dapat diketahui bahwa ibu bersalin di Puskesmas Karangdoro yang mendapat pendampingan yang baik dari keluarga sebagian besar mengalami proses persalinan yang cepat (kurang dari 2 jam) sebanyak $21 \quad(53,8 \%)$ reponden dan pada ibu bersalin di Puskesmas Karangdoro yang kurang mendapatkan pendampingan keluarga sebagian besar mengalami persalinan yang lambat dalam persalinan sebanyak $8 \quad(20,5 \%)$ reponden.

Berdasarkan hasil analisa data dengan menggunakan perhitungan secara statistik melalui uji Chi Square dengan derajat kepercayaan $(95 \%)$ dengan kebebasan (df) $=2$, setelah data diolah ternyata terdapat 1 sel $(25 \%)$ yang mempunyai nilai harapan $<5$ sehingga tidak memenuhi persyaratan uji Chi square memenuhi persyaratan uji chi square, sehingga dianalisis menggunakan Fisher Exact dengan tingkat probabilitas $\alpha: 0,05$. Dari hasil olah data didapatkan nilai continuity correction sebesar 5,331 dengan $\mathrm{p}$ value fisher exact sebesar 0,012< 0,05, maka Berdasarkan kriteria penolakan Ho dapat dinyatakan hipotesa (Ho) ditolak dan hipotesa (Ha) diterima berarti ada hubungan yang bermakna antara pendampingan keluarga dengan lama proses persalinan di Puskesmas Karangdoro Semarang.

Keberadaan pendamping akan membawa dampak yang baik pada proses persalinan karena dapat memberikan dukungan, semangat, dan rasa aman. Keuntungan pendamping persalinan oleh keluarga dapat mengurangi rasa cemas, mempermudah atau mempercepat proses persalinan serta dapat menghindari komplikasi-komplikasi pada persalinan, dapat mengurangi nilai skore APGAR $<7$ pada bayi baru lahir sehingga menghindari bayi asfeksia, Dengan pendampingan keluarga waktu yang di butuhkan dalam menghadapi persalinan semakin pendek, kepuasan ibu semakin meningkat dalam pengalaman melahirkan, persalinan yang diakhiri dengan vacuum ekstraksi, fosceps, dan secsio cesaria semakin menurun.

Hal tersebut dapat ditunjukan dengan ibu bersalin di Puskesmas Karangdoro yang mendapat pendampingan yang baik dari 
keluarga sebagian besar mengalami proses persalinan yang cepat (kurang dari 10 jam) sebanyak 18 responden $(75 \%)$ dan pada ibu bersalin di Puskesmas Karangdoro yang kurang mendapatkan pendampingan keluarga sebagian besar mengalami persalinan yang lambat dalam persalinan sebanyak 6 responden $(66,7 \%)$.

\section{KESIMPULAN}

1. Sebagian besar ibu dalam proses persalinan kala 1 di puskesmas Karangdoro Kota Semarang mendapatkan pendampingan keluarga yang baik selama proses persalinan kala 1 sebanyak 27 responden $(69,2 \%)$.

2. Sebagian besar ibu bersalin di Puskesmas Karangdoro Kota Semarang mengalami proses persalinan kala 1 yang cepat sebanyak 25 responden $(64,1 \%)$.

3. Ada hubungan yang bermakna antara pendampingan keluarga dengan lama proses persalinan di Puskesmas Karangdoro Semarang dengan nilai continuity correction sebesar 5,331 dengan $\mathrm{p}$ value fisher exact sebesar $0,012<0,05$.

\section{DAFTAR PUSTAKA}

Arikunto, Suharsini. (2006). Prosedur Penelitian Suatu pendekataan Praktikan. Jakarta : PT. Rineka Cipta.

Budiarto, Eko. (2004). Metode Penelitian Kedokteran, Sebuah Pengantar. Jakarta : EGC.

Burns, A. (2000). Pemberdayaan Wanita Dalam Bidang

Kesehatan. Yogyakarta Yayasan Essentia.

Damin, Sudarwan. (2004). Metode penelitian untuk Ilmu-ilmu Prilaku. Jakarta : Bumi Angkasa.

Danuatmaja, Bonny. (2003). 40 Hari Pasca Persalinan.Jakarta: puspa Swara.
Hurlock, B. Elizabeth. (2003). Psikogi Perkembangan Suatu

Pendekatan Sepanjang Rentang Kehidupan. Edisi ke5. Jakarta : Erlangga.

Maulana, Mirza. (2008). panduan lengkap kehamilan, memahami kesehatan reproduksi, cara menghadapi persalinan aman, kiat mengasuh anak. Yogyakarta : katahari.

Nototmodjo,

Soekidjo. (2003).Pendidikan dan Prilaku Kesehatan.Jakarta: PT. Rineka cipta.

Nursalam dan Pariani.(2003). Konsep dan penerapan Metodolagi Penelitian ilmu Keperawatan.Jakarta: Salemba Medika.

Nolan.(2003).Persalinan Sehat. Jakarta: Salemba Medika

Prawirohardjo, sarwono. (2002). Buku Panduan Praktis Pelayanan Kesehatan Maternal dan Neonatal. Jakarta : Yayasan bina pustaka sarwono prawirohardjo.

Pemerintah Propinsi Jateng, Dinkes. (2011).Profil Kasehatan Profinsi Jateng Tahun 2011.Semarang : Dinkes.

Pemerintah Dinas Kesehatan Kota Semarang. (2011). Profil Kasehatan kota Semarang Tahun 2011. Semarang : Dinkes.

Peny Simpkin.2008. persalinan. Avaible.htt: //www.mailarchive.com/persalinan aman@.com/ ms 9100971.html.

Purwaningrum.2001. pendamping melahirkan.Avaible.htt: //www.net.idarchive.com/persalinan aman@.com/ ms 8810297.html.

Saifuddin, Abdul Bari, dkk. (2006). Buku acuan Nasional Pelayanan Kesehatan Maternal 
Jurnal Kebidanan, 6 (2), 2017, 79

dan Neonatal Ed.1cet. 4. Sukmadinata.(2003).Landasan

Jakarta : Yayasan Bina Pustaka

Psikologi. Bandung: PT Sarwono Prawirohardjo.

Sujiyatini, dkk. (2011). Asuhan Kebidanan II persalinan. Yogyakarta : Yayaasan Essetia. Remaja Rosdakarya.

Waspodo, djoko.2008. Asuhan Persalinan Normal dan Inisiasi Menyusu Dini. Jakarta: Salemba Medika. 